\title{
Pengaruh Perputaran Kas, Kecukupan Modal, dan Risiko Kredit Pada Profitabilitas LPD di Kabupaten Gianyar
}

\author{
Sang Ayu Diah Febriani ${ }^{1}$ \\ Fakultas Ekonomi dan Bisnis \\ Universitas Udayana, Indonesia. \\ Email: diahfebriani79@gmail.com
}

\author{
I Made Sadha Suardikha ${ }^{2}$ \\ Fakultas Ekonomi dan Bisnis \\ Universitas Udayana, Indonesia.
}

\begin{abstract}
ABSTRAK
Penelitian ini bertujuan untuk mengetahui faktor-faktor yang mempengaruhi profitabilitas LPD dengan menggunakan variabel perputaran kas, kecukupan modal dan risiko kredit. Penelitian ini menghipotesiskan perputaran kas, kecukupan modal, dan risiko kredit dan profitabilitas LPD .Penelitian ini bertempat di LPD Kabupaten Gianyar. Metode pengambilan sampel menggunakan probability sampling denganteknik proportional stratified random sampling. Data penelitian bersumber dari data laporan keuangan LPD yang tercatat di LPLPD Kabupaten Gianyar. Analisis data penelitian menggunakan regresi linear berganda. Hasil penelitian menunjukkan perputaran kas dan kecukupan modal berpengaruh positif pada profitabilitas LPD di Kabupaten Gianyar. Sedangkan risiko kredit berpengaruh negatif pada profitabilitas LPD di Kabupaten Gianyar. Berdasarkan hasil penelitian diharapkan pihak LPD mampu menjaga tingkat perputaran kas, kecukupan modal, serta tingkat risiko kredit.
\end{abstract}

Kata Kunci : $\quad$ Profitabilitas; Perputaran Kas; Kecukupan Modal; Risiko Kredit.

\section{Effects of Cash Turnover, Capital Adequacy, and Credit Risk on LPD Profitability in Gianyar Regency}

\section{ABSTRACT}

This study aims to determine the factors that affect the profitability of LPDs by using variable cash turnover, capital adequacy and credit risk. This study hypothesizes cash turnover, capital adequacy, and credit risk and LPD profitability. This research took place in the LPD of the Regency of Gianyar. The sampling method uses probability sampling with proportional stratified random sampling technique. The research data were sourced from LPD financial report data recorded in the Gianyar Regency LPLPD. Analysis of research data using multiple linear regression. The results showed that cash turnover and capital adequacy has a positive effect on LPD profitability in Gianyar Regency. But, credit risk has a negative effect on the profitability of LPDs in Gianyar Regency. Based on the results of the study it is expected that the LPD is able to maintain the level of cash turnover, capital adequacy, and the level of credit risk.

Keywords: $\quad$ Profitability; Cash Turnover; Capital Adequacy; Credit Risk.

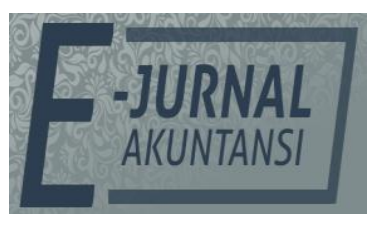

E-JA

e-JurnalAkuntansi e-ISSN 2302-8556

Vol. 8 No. 2

Denpasar, Oktober

2019

Hal. 308-324

Artikel masuk:

26 Agustus 2019

Tanggal diterima:

29 September 2019 


\section{PENDAHULUAN}

Lembaga keuangan ialah lembaga perantara keuangan sebagai perantara pendukung yang sangat penting guna menjunjung kelancaran perekonomian. Lembaga keuangan pada dasarnya memiliki fungsi mentransfer dana dari penabung kepada para peminjam (Wiwoho, 2014). Salah satu lembaga keuangan yang terdapat di Bali, yaitu Lembaga Perkreditan Desa (LPD). LPD ialah badan usaha keuangan milik desa adat dan melaksanakan kegiatan usaha di lingkungan desa adat. LPD adalah salah satu aset dan sumber pendapatan desa adat sehingga memerlukan pengelolaan yang baik oleh pengurus dan badan pengawas (Darsana, 2010:2). Dewasa ini, pertumbuhan lembaga keuangan baru milik pemerintah maupun swasta serta LPD menjadi tantangan bagi LPD untuk tetap menjaga eksistensinya di dalam ketatnya persaingan dunia usaha. Analisis tingkat kesehatan lembaga keuangan bertujuan untuk menganalisis kekuatan maupun kelemahan suatu lembaga keuangan serta mengevaluasi kinerja lembaga keuangan dan memprediksi kinerja lembaga keuangan kedepannya (Kosmidou \& Zopounidis, 2008). Dengan kinerja lembaga keuangan yang baik, maka tingkat kepercayaan masyarakat terhadap lembaga keuangan makin meningkat. Namun, sebaliknya bila kinerja lembaga keuangan menurun maka tingkat kepercayaan nasabah berkurang. Kepercayaan ini akan menciptakan kepuasan nasabah sehingga akan berpengaruh terhadap loyalitas nasabah (Jiang \& Rosenbloom, 2005).

Kesehatan suatu LPD erat kaitannya dengan kinerja keuangan LPD itu sendiri. Faktor penilaian tingkat kesehatan LPD terdiri dari 5 aspek yaitu kecukupan modal, kualitas aktiva produktif, manajamen, laba dan likuiditas. Berdasarkan hasil penilaian tingkat kesehatan LPD peringkat kesehatan LPD terditi dari 4 peringkat, yaitu sehat, cukup sehat, kurang sehat dan tidak sehat (Peraturan Gubernur No. 13 tahun 2017). Dalam hal ini indikator kinerja keuangan yang dapat digunakan adalah perolehan laba. Berikut merupakan grafik perolehan laba tahun berjalan LPD di Kabupaten Gianyar tahun 2013-2017.

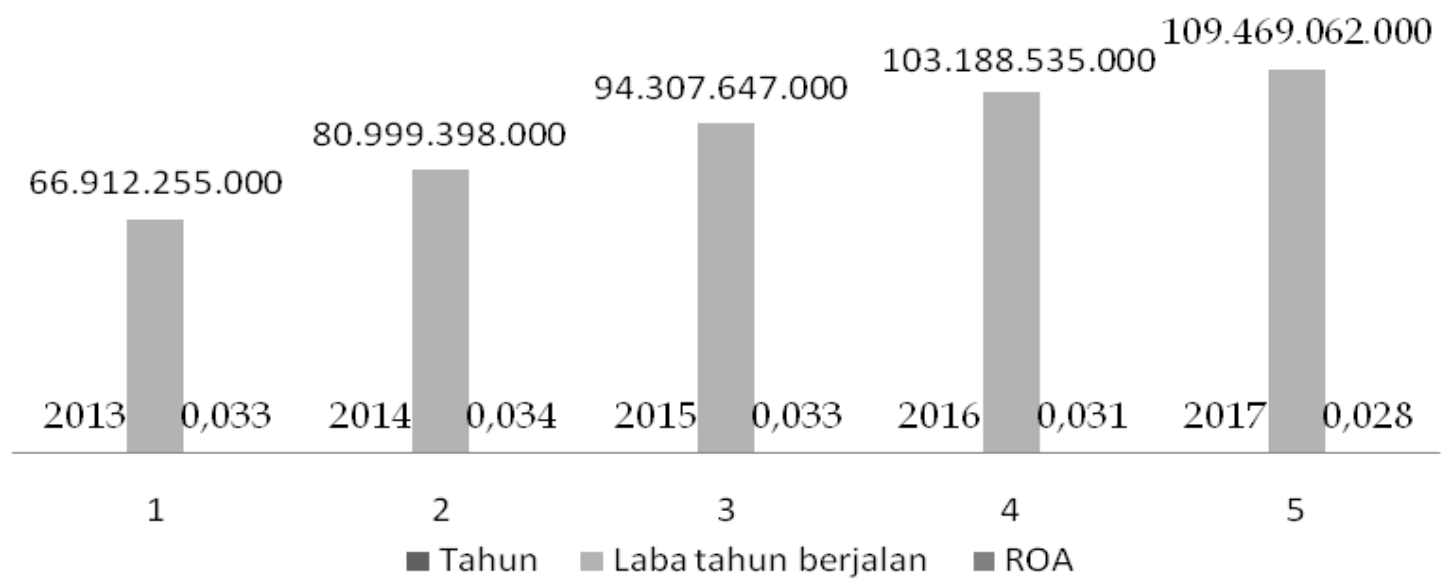

Gambar 1. Perolehan laba LPD Kabupaten Gianyar tahun 2013-2017

Sumber: LPLPD Kabupaten Gianyar, 2018

Berdasarkan grafik di atas terlihat perolehan laba dari tahun 2013 sampai dengan 2017 mengalami peningkatan setiap tahunnya. Namun jika dilihat pertumbuhan profitabilitas yang diukur menggunakan Return On Asset (ROA) terjadi penurunan profitabilitas dari tahun 2015 sampai dengan tahun 2017.

Kemampuan lembaga keuangan untuk menghasilkan laba dari aktivitas operasional lembaga keuangan tersebut dicerminkan oleh profitabilitas atau laba suatu lembaga keuangan (Lee \& Rose, 2010). Rasio profitabilitas ekonomi merupakan salah 
satu alat untuk mengukur kinerja LPD. Istilah pertumbuhan profitabilitas dikemukakan oleh Susan (2006: 58), yang didefinisikan sebagai adanya kenaikan atau penurunan profitabilitas yang digunakan untuk mengukur kemampuan suatu perusahaan untuk menghasilkan laba selama periode tertentu dan untuk melihat kemampuan suatu perusahaan dalam beroperasi secara efisien. Pertumbuhan profitabilitas memberikan gambaran tentang kemampuan perusahaan dalam memperoleh laba pada periode tertentu. Semakin besar profitabilitas maka semakin baik, karena kemakmuran dan tingkat kesehatan LPD meningkat dengan semakin besarnya profitabilitas. Profitabilitas akan menjadi ukuran dari prestasi yang diraih oleh suatu LPD. Profitabilitas merupakan orientasi bagi LPD agar dapat terus tumbuh dan berkembang.

Tingkat perputaran kas adalah periode berputarnya kas yang dimulai saat kas diinvestasikan dalam kelompok modal kerja sampai saat kembali menjadi kas (Friskayanti, 2014). Menurut Sutika \& Sujana (2013) jumlah uang kas yang besar menunjukkan banyaknya dana yang tertanam pada kas dalam keadaan menganggur dan hal tersebut akan mempengaruhi profitabilitas perusahaan. Besar kecilnya kas dan tinggi rendahnya tingkat perputaran kas akan mencerminkan efisiensi penggunaan kas dalam perusahaan, semakin besar jumlah uang kas berarti semakin banyak dana yang tertanam pada kas dalam keadaan menganggur dan ini akan mempengaruhi profitabilitas LPD (Prawira \& Wisadha, 2012). Tingginya tingkat perputaran kas pada LPD dapat diartikan sebagai semakin tingginya efisiensi penggunaan kas sehingga akan berpengaruh pada profitabilitas LPD. Perputaran kas yang berlebihan juga dapat diartikan bahwa jumlah kas yang tersedia terlalu kecil sehingga dapat mengganggu kelancaran operasional LPD.

Modal (Capital) merupakan salah satu faktor penting bagi keberlangsungan suatu LPD, karena dengan modal yang dimiliki LPD dapat menyalurkan dananya ke masyarakat. Modal juga merupakan faktor yang penting dalam pengembangan usaha dan untuk menampung risiko kerugian (Lely, 2007). Menurut Vong \& Chan (2014) menunjukkan bahwa kekuatan modal dari suatu lembaga keuangan sangat penting dalam mempengaruhi profitabilitas. Hal ini karena rasio modal telah lama menjadi alat yang berharga untuk menilai kecukupan modal dan sebagai faktor mencapai keamanan umum dan kesehatan bank. Tingkat kecukupan modal diperlukan untuk melindungi lembaga keuangan dari risiko serta menjamin keberlanjutan lembaga keuangan. Tingkat kecukupan modal yang lebih tinggi mampu meningkatkan tingkat profitabilitas karena dengan memiliki lebih banyak modal, lembaga keuangan dapat dengan mudah mematuhi standar peraturan permodalan sehingga kelebihan modal dapat diberikan sebagai pinjaman (Friskayanti, 2014).

Kelangsungan lembaga keuangan sangatlah dipengaruhi oleh sejumlah kredit yang disalurkan dalam satu periode. Artinya, semakin banyak kredit yang disalurkan, semakin besar pula perolehan laba (Friskayanti, 2014). Peningkatan maupun penurunan profitabilitas dipengaruhi oleh beberapa faktor salah satunya risiko kredit. Hal ini karena kerugian terbesar dari pendapatan datang dari pinjaman dari mana bunga itu diturunkan. Penyaluran kredit merupakan sumber pendapatan terbesar dari LPD. Penyaluran kredit, yatu kegiatan atau aktivitas menyalurkan kembali simpanan yang diterima dari nasabah kepada masyarakat yang membutuhkan dana dalam bentuk kredit selama jangka waktu tertentu (Indah Lestari \& Suartana, 2017). Risiko kredit adalah risiko yang berhubungan dengan sejumlah besar aset yang menghasilkan pendapatan serta merupakan penentu kinerja bank (Gizaw, et. al, 2015). 
Hasil penelitian Prawira, (2012) menunjukkan variabel tingkat perputaran kas berpengaruh positif pada profitabilitas LPD di Kota Denpasar periode 2006-2010. Hal ini sejalan dengan penelitian yang dilakukan oleh Friskayanti (2014) menyatakan terdapat pengaruh yang positif antara tingkat perputaran kas terhadap profitabilitas Lembaga Perkreditan Desa diseluruh LPD Kabupaten Buleleng yang terdaftar pada LPLPD. Namun terdapat perbedaan hasil penelitian yang dilakukan oleh Suteja Putra (2013) yang menyatakan bahwa tingkat perputaran kas tidak berpengaruh positif pada profitabilitas LPD di Kecamatan Ubud.

Penelitian yang dilakukan Ani et. al. (2012) CAR berpengaruh positif terhadap profitabilitas. Sejalan dengan penelitian Paramithari (2016) yang menyatakan CAR berpengaruh positif pada pertumbuhan laba pada LPD Kabupaten Badung. Sedangkan penelitian yang dilakukan oleh Obicks (2010) menyatakan bahwa kecukupan modal tidak berpengaruh terhadap profitabilitas LPD. Hal ini sejalan dengan penelitian yang dilakukan oleh Windi (2015) yang menyatakan kecukupan modal (CAR) tidak berpengaruh pada profitabilitas (ROA) di LPD Kabupaten Badung. Penelitian yang dilakukan oleh Ariani \& Ardiana (2015) menunjukkan risiko kredit (NPL) memilki pengaruh negarif pada profitabilitas (ROA). Penelitian Yanti \& Suryantini (2015) menunjukkan risiko kredit berpengaruh negatif terhadap profitabilitas. Hal ini sejalan dengan penelitian yang dilakukan oleh Noman, et. al (2015) yang menyatakan NLP berpengaruh negatif terhadap profitabilitas, serta NPL dapat mengurangi profitabilitas. Namun, hasil penelitian Sukarno \& Syaichu (2006) menyatakan bahwa NLP berpengaruh positif tidak signifikan terhadap ROA.

Perbedaan hasil penelitian tersebut menjadi suatu kesenjangan (research gap) antara penerapan teori yang selama ini dianggap benar pada industri perbankan dengan kondisi empiris bisnis perbankan. Oleh karena itu, penelitian lanjutan ini dilakukan oleh penulis guna mengetahui faktor-faktor yang mempengaruhi profitabilitas. Sehingga peneliti tertarik untuk mengambil judul "Pengaruh Perputaran Kas, Kecukupan Modal, dan Risiko Kredit Pada Profitabilitas LPD di Kabupaten Gianyar. Penelitian ini bertujuan untuk mengetahui pengaruh perputaran kas, kecukupan modal, risiko kredit pada profitabilitas LPD di Kabupaten Gianyar.

Teori sinyal menjelaskan alasan perusahaan untuk memberikan informasi terkait aktivitas bisnisnya kepada pihak eksternal, seperti investor, kreditur dan masyarakat. Menurut Sari (2008) teori sinyal menjelaskan mengapa lembaga keuangan mempunyai dorongan untuk memberikan informasi laporan keuangan kepada pihak eksternal. Dorongan tersebut timbul karena adanya informasi asimetris antara manajemen LPD dengan pihak luar, dimana manajemen mengetahui informasi internal LPD yang relatif lebih banyak dan lebih cepat dibandingkan dengan pihak luar seperti investor, kreditur, dan masyarakat. Perusahaan pun harus mengungkapkan informasi yang dimilikinya, salah satunya adalah laporan mengenai CSR, untuk mengurangi adanya asimetris informasi tersebut (Rustiarini, 2010).

Profitabilitas merupakan suatu ukuran dalam persentase yang digunakan untuk menilai sejauh mana perusahaan mampu menghasilkan laba pada tingkat yang dapat diterima (Manik, 2018). Laba dapat diperoleh dari pendapatan yang merupakan total manfaat yang dihasilkan oleh semua infrastuktur perusahaan (Bratland, 2010). Profitabilitas yaitu kemampuan perusahaan untuk menghasilkan keuntungan dan mengukur tingkat efisiensi operasional dan efisiensi dalam menggunakan harta yang dimilikinya (Chen \& Chen, 2011). Profitabilitas suatu bank menunjukkan perbandingan laba setelah pajak dengan modal inti atau laba sebelum pajak dengan total aset yang dimiliki oleh bank pada periode tertentu (Riyadi, 2006:155). 
Profitabilitas pada LPD memiliki peranan yang penting, karena mampu meningkatkan taraf hidup LPD, profitabilitas pula akan mensejahterakan masyarakat banyak. Rasio profitabilitas dapat dilihat dari berbagai macam rasio, seperti return on equity (ROE) dan return on asset (ROA) untuk perusahaan pada umumnya. ROA memfokuskan kemampuan perusahaan untuk memperoleh earning dalam operasi perusahaan sedangkan ROE hanya mengukur return yang diperoleh dari investasi pemilik perusahaan dalam bisnis tersebut.

ROA merupakan rasio profitabilitas yang sangat penting bagi bank, karena rasio ini digunakan bank untuk mengukur seberapa besar efektivitas dari bank tersebut dalam mencapai keuntungan dengan memanfaatkan aktiva yang dimiliki oleh bank termasuk LPD (Krisna, 2017). Dalam penentuan tingkat kesehatan bank, Bank Indonesia lebih mementingkan penilaian besarnya ROA, karena Bank Indonesia sebagai pembina dan pengawas perbankan lebih mengutamakan nilai profitabilitas suatu bank diukur dengan aset yang dananya sebagian besar berasal dari dana simpanan masyarakat (Mirah, 2016). ROA merupakan perhitungan rasio yang membandingkan tingkat laba bersih setelah pajak dengan total seluruh aktiva yang dimiliki perusahaan. ROA digunakan untuk mengukur efektivitas perusahaan didalam menghasilkan keuntungan dengan memanfaatkan aktiva yang dimilikinya. Semakin tinggi ROA suatu bank, maka semakin besar keuntungan yang diperoleh bank tersebut yang berarti bahwa bank mampu memanfaatkan aktiva yang dimiliki dengan baik (Mirah, 2016). Peraturan Gubernur Bali Nomor 11 Tahun 2013 tentang LPD, ROA dimaksudkan untuk menilai kemampuan LPD dalam menghasilkan laba terhadap rata-rata asset yang dimiliki.

Perputaran kas merupakan perbandingan antara penjualan bersih dengan jumlah rata-rata kas. Perputaran kas menunjukkan kemampuan kas dalam menghasilkan pendapatan, sehingga dapat dilihat berapa kali uang kas berputar dalam satu periode tertentu (Rahma, 2011). Kas memiliki tingkat likuiditas yang paling tinggi, yang berarti semakin besar jumlah kas yang dimiliki perusahaan maka semakin rendah tingkat perputarannya. Hal ini mencerminkan adanya over investment dalam kas yang menunjukkan bahwa perusahaan kurang efisien di dalam mengelola kas (Suteja Putra \& Wirajaya, 2013). Sebaliknya, semakin tinggi perputaran kas maka semakin baik, ini berarti semakin tinggi efisiensi penggunaan kasnya dan keuntungan yang diperoleh akan semakin besar.

Secara teoritis praktek perputaran kas merupakan perbandingan antara jumlah penjualan dengan kas rata-rata (Riyanto, 2011:95). Besar kecilnya kas dan tinggi rendahnya tingkat perputaran kas akan mencerminkan efisiensi penggunaan kas dalam perusahaan berputar saat diinvestasikan (Suteja Putra \& Wirajaya, 2013). Semakin besar jumlah uang kas berarti semakin banyak dana yang tertanam pada kas dalam keadaan menganggur, dan ini akan mempengaruhi profitabilitas LPD.

Penelitian yang dilakukan oleh Prawira (2012) menunjukkan variabel tingkat perputaran kas berpengaruh pada profitabilitas LPD di Kota Denpasar periode 20062010. Hal ini sejalan dengan penelitian yang dilakukan oleh Friskayanti (2014) menyatakan terdapat pengaruh yang positif antara tingkat perputaran kas terhadap profitabilitas Lembaga Perkereditan Desa diseluruh LPD Kabupaten Buleleng yang terdaftar pada LPLPD. Penelitian yang dilakukan oleh Suteja (2013) juga menunjukkan bahwa tingkat perputaran kas memiliki pengaruh positif pada profitabilitas LPD di Kecamatan Ubud.Sejalan dengan penelitian yang dilakukan oleh Dewi (2017) yang menyatakan bahwa perputaran kas berpengaruh positif terhadap pertumbuhan laba 
LPD Kabupaten Gianyar. Berdasarkan pemaparan di atas maka hipotesis yang dapat dirumuskan sebagai berikut:

$\mathrm{H}_{1}$ : Perputaran kas berpengaruh positif pada profitabilitas LPD di Kabupaten Gianyar

Modal (capital) sering juga disebut sebagai rasio-rasio solvabilitas atau capital adequacy ratio. Analisis solvabilitas digunakan untuk: pertama sebagai ukuran kemampuan lembaga keuangan tersebut untuk menyerap kerugian-kerugian yang tidak dapat dihindarkan. Pada penelitian ini rasio yang digunakan untuk mengukur kecukupan modal LPD yaitu Capital Adequacy Ratio (CAR). Menurut Kuncoro dan Suhardjono (2011:519) CAR merupakan kecukupan modal yang menunjukkan kemampuan bank dalam mempertahankan modal yang mencukupi dan kemampuan manajemen bank dalam mengidentifikasi, mengukur, mengawasi dan mengontrol risiko-risiko yang muncul yang dapat mempengaruhi besarnya modal bank. CAR digunakan untuk mengukur kemampuan permodalan yang ada untuk menutup kemungkinan kerugian di dalam kegiatan perkreditan dan perdagangan surat-surat berharga.

Menurut Yuanjuan \& Shishun (2012) rasio kecukupan modal merupakan indeks yang komprehensif untuk mencerminkan risiko, tetapi juga perlu memperhatikan asset dan kewajiban. Peraturan Gubernur Nomor 44 tahun 2017 tentang LPD menyebutkan bahwa LPD harus memenuhi kecukupan modal minimum yaitu sebesar $12 \%$. Kecukupan modal ini ditentukan berdasarkan perbandingan antara modal LPD dengan ATMR (Aktiva Tertimbang Menurut Risiko). Tujuan utama dari CAR yaitu untuk mengetahui apakah permodalan tersebut akan mampu untuk menyerap kerugian-kerugian lembaga keuangan yang terjadi dalam melakukan penanaman dana atau penurunan aktiva di kemudian hari. Semakin besarnya modal yang dimiliki oleh suatu lembaga keuangan akan meningkatkan rasio kecukupan modalnya, sebaliknya bila modal lembaga keuangan terus menerus terkikis oleh kerugian yang dialami lembaga keuangan, maka rasio kecukupan modalnya akan turun, hal ini diakibatkan oleh kerugian yang dialami oleh lembaga keuangan sehingga menyerap modal yang dimilikinya.

Modal LPD yang dimaksud tediri dari modal inti dan modal pelengkap. Modal inti terdiri dari modal disetor, modal donasi, modal cadanan, modal tahun lalu dan laba tahun berjalan diperhitungkan $50 \%$. Sedangkan modal pelengkap terdiri dari akumulasi penyusutan aktiva tetap serta inventaris dan CPRR (Cadangan Pinjaman Ragu-Ragu). ATMR terdiri dari aktiva neraca LPD yang diberikan bobot sesuai dengan kadar risiko yang melekat pada setiap pos aktiva. Kadar risiko setiap pos aktiva ditetapkan sebagai berikut (Peraturan Gubernur Nomor 44 tahun 2017) : 1) Kas 0\%, 2) Antar Aktiva LPD 20\%, 3) Antar Aktiva LPD pada kondisi macet 100\%, 4) Pinjaman yang diberikan $100 \%$, 5) Aktiva tetap dan inventaris 100\%, 6) Aktiva lain/ rupa-rupa aktiva $100 \%$.

Penelitian yang dilakukan oleh Pudja (2014) menyatakan bahwa kecukupan modal berpengaruh signifikan terhadap profitabilitas LPD. Sejalan dengan penelitina yang dilakukan oleh Dania (2015) yang menyatakan bahwa CAR berpengaruh terhadap profitabilitas LPD di Kabupaten Badung. Hasil penelitian yang dilakukan oleh Olalekan \& Adeyinka (2013) menyatakan bahwa CAR berpengaruh positif terhadap ROA. Hal ini sejalan dengan penelitian yang dilakukan oleh Krisna (2015) yang menyatakan bahwa kecukupan modal berpengaruh positif terhadap profitabilitas LPD se-Kabupaten Badung. Berdasarkan pemaparan di atas maka hipotesis yang dapat dirumuskan sebagai berikut : 
$\mathrm{H}_{2}$ : Kecukupan modal berpengaruh positif pada profitabilitas LPD di Kabupaten Gianyar.

Risiko kredit yaitu suatu risiko kerugian yang disebabkan oleh ketidak mampuan dari debitur atas kewajiban pembayaran utang, baik utang pokok maupun bunganya atau keduanya (Yanti \& Suryantini, 2015). Rasio yang digunakan untuk mengukur risiko kredit yaitu Non Performing Loan (NPL). NPL merupakan rasio yang digunakan untuk mengukur kemampuan manajemen bank dalam mengelola kredit macet yang diberikan oleh bank (Krisna, 2017). Berdasarkan Surat Edaran Bank Indonesia No.8/31/DPBPR tanggal 12 Desember 2006, NPL bertujuan untuk mengetahui jumlah nominal kredit dengan kualitas kurang lancar, diragukan, dan macet. NPL ialah cerminan dari risiko kredit, dimana semakin rendah tingkat NPL maka semakin rendah pula risiko kredit yang ditanggung oleh pinak bank, begitu pula sebaliknya. Menurut Haneef et.al. (2012) NPL dianggap sebagai ketentuan mekanisme kendali atas kerugian pinjaman yang diharapkan oleh perusahaan. Riyadi (2006: 161) menyatakan besarnya NPL yang diperbolehkan oleh Bank Indonesia adalah maksimal $5 \%$, jika besarnya NPL melebihi 5\%, maka memengaruhi penilaian tingkat kesehatan bank yang bersangkutan, dimana hal tersebut akan mengurangi nilai yang akan diperoleh oleh bank itu sendiri.

Penelitian yang dilakukan oleh Ariani \& Ardiana (2015) menunjukkan risiko kredit (NPL) memilki pengaruh negarif pada profitabilitas (ROA). Penelitian Yanti \& Suryantini (2015) menunjukkan risiko kredit berpengaruh negatif terhadap profitabilitas. Hal ini sejalan dengan penelitian yang dilakukan oleh Noman, et al. (2015) yang menyatakan NLP berpengaruh negatif terhadap profitabilitas, serta NPL dapat mengurangi profitabilitas. Namun, hasil penelitian Sukarno \& Syaichu (2006) menyatakan bahwa NLP berpengaruh positif tidak signifikan terhadap ROA. Berdasarkan pemaparan di atas maka hipotesis yang dapat dirumuskan sebagai berikut :

$\mathrm{H}_{3}$ : Risiko kredit berpengaruh negatif pada profitabilitas LPD di Kabupaten Gianyar.

Berdasarkan hipotesis diatas, maka terbentuklah kerangka konseptual dalam penelitian ini sebagai berikut:

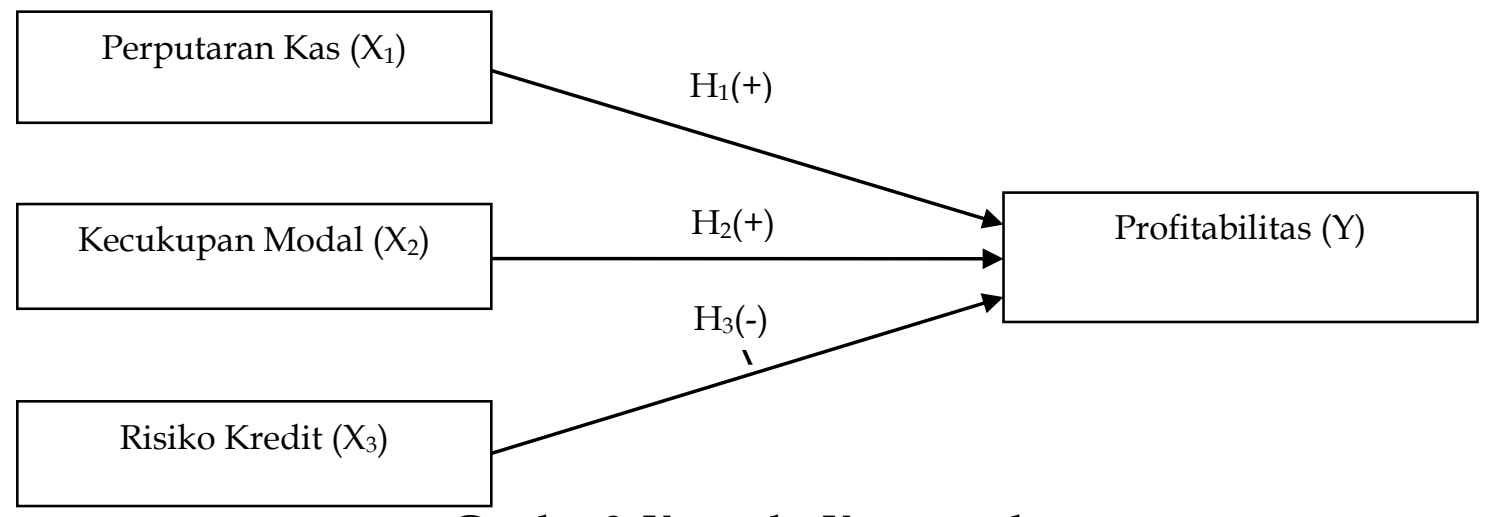

Gambar 2. Kerangka Konseptual.

Sumber: Data Penelitian, 2018

\section{METODE PENELITIAN}

Penelitian ini menggunakan pendekatan kuantitatif yang berbentuk asosiatif. Pengamatan dalam penelitian ini adalah di LPD Kabupaten Gianyar. Alasan dipilihnya lokasi penelitian tersebut karena LPD di Kabupaten Gianyar memiliki total laba yang meningkat setiap tahunnya dari tahun 2013-2017. Namun terjadi penurunan nilai profitabilitas yang diukur menggunakan ROA dari tahun 2015 sampai 2017. Sehingga 
peneliti tertarik untuk meneliti LPD yang terdapat di Kabupaten Gianyar. Variabel terikat $(Y)$ dalam penelitian ini yaitu profitabilitas LPD di Kabupaten Gianyar. Variabel bebas dalam penelitian ini yaitu perputaran kas $\left(X_{1}\right)$, kecukupan modal $\left(X_{2}\right)$, risiko kredit $\left(X_{3}\right)$.

Profitabilitas merupakan variabel terikat yang dapat diukur atau diproksikan dengan ROA dengan membandingkan antara laba bersih dengan total aktiva. ROA ialah rasio yang digunakan untuk mengukur kemampuan perusahaan dalam menghasilkan laba yang berasal dari aktiva investasi (Mardiyanto, 2009). Adapun rumus perhiungannya:

$$
\text { ROA }=\frac{\text { Laba Bersih }}{\text { Total Aktiva }} \times 100 \% .
$$

Perputaran kas merupakan perbandingan antara penjualan bersih dengan jumlah rata-rata kas. Perputaran kas menunjukkan kemampuan kas dalam menghasilkan pendapatan, sehingga dapat dilihat berapa kali uang kas berputar dalam satu periode tertentu (Rahma, 2011). Semakin tinggi perputaran kas maka semakin baik, ini berarti semakin tinggi efisiensi penggunaan kasnya dan keuntungan yang diperoleh akan semakin besar. Perputaran kas dengan diukur dengan rumus sebagai berikut:

$$
\begin{aligned}
& \text { Perputaran kas }=\frac{\text { pendapatan operasional }}{\text { rata }- \text { rata }} \\
& \text { Rata-rata kas }=\frac{\text { kas awal +kas akhir }}{2} \text {. }
\end{aligned}
$$

Modal LPD merupakan dana yang diinvestasikan oleh pemilik untuk membiayai kegiatan usaha LPD yang jumlahnya telah ditetapkan pada saat pendirian LPD tersebut. Kecukupan modal dalam penelitian ini diukur dengan menggunakan rasio CAR dengan membandingkan antara jumlah modal dengan Aktiva Tertimbang Menurut Resiko (ATMR). CAR adalah suatu kewajiban bank atau lembaga perbankan dan LPD dalam memenuhi tingkat kecukupan pemenuhan modal yang memadai untuk menjaga likuiditasnya. Adapun rumus yang digunakan untuk menghitung CAR yaitu:

$$
\text { CAR }=\frac{\text { Modal LPD }}{\text { Total ATMR }} \times 100 \% .
$$

Risiko kredit dalam penelitain ini diukur dengan menggunakan rasio NPL. NPL ialah cerminan dari risiko kredit, dimana semakin rendah tingkat NPL maka semakin rendah pula risiko kredit yang ditanggung oleh pinak bank, begitu pula sebaliknya. Adapun rumus yang digunakan untuk mengukur rasio NPL (Surat Edaran BI No. 13/30/DPNP) yaitu:

$$
\mathrm{NPL}=\frac{\text { KreditBermasalah }}{\text { Total Kredit }} \times 100 \% .
$$

Jenis data yang digunakan dalam penelitian ini yaitu jenis data kuantitatif. Data kuantitatif merupakan data dalam bentuk angka atau data kualitatif yang diangkakan atau scoring. Data kuantitatif dalam penelitian ini berupa laporan keuangan LPD yang ada di Kabupaten Gianyar periode Desember 2013 sampai dengan Desember 2017. Sumber data yang digunakan dalam penelitian ini yaitu sumber data sekunder. Data sekunder dalam penelitian ini berupa laporan keuangan LPD yang ada di Kabupaten Gianyar dari Desember 2013 sampai dengan Desember 2017.

Populasi dalam penelitian ini adalah seluruh LPD di Kabupaten Gianyar yang terdaftar di LPLPD Kabupaten Gianyar. Dimana populasi dalam penelitian ini sebanyak 270 LPD di Kabupaten Gianyar (LPLPD Kabupaten Gianyar, 2017). Metode pengambilan sampel yang digunakan dalam penelitian ini yaitu probability sampling dengan teknik proportional stratified random sampling. Probability sampling merupakan teknik pengambilan sampel yang memberikan peluang yang sama bagi setiap unsur 
(anggota) populasi untuk dipilih menjadi anggota sampel. Penentuan jumlah proporsi sampelnya dilakukan dengan menggunakan rumus Slovin. Tingkat presisi yang ditetapkan dalam penentuan sampel adalah $10 \%$. Adapun rumus Slovin adalah sebagai berikut:

$$
\mathrm{n}=\frac{\mathrm{N}}{1+\mathrm{Ne}^{2}}
$$

Keterangan :

$$
\begin{aligned}
& \mathrm{n}=\text { ukuran sampel } \\
& \mathrm{N}=\text { ukuran populasi } \\
& \mathrm{e}=\text { tingkat kesalahan } \\
& \text { maka diperoleh perhitungan jumlah sampel sebagai berikut : } \\
& \mathrm{n}=\frac{\mathrm{N}}{1+\mathrm{Ne}^{2}} \\
& \mathrm{n}=\frac{270}{1+270(0,1)^{2}} \\
& \mathrm{n}=73
\end{aligned}
$$

Perhitungan untuk masing-masing sampel yang akan diambil setiap kecamatan di Kabupaten Gianyar yaitu:

Kecamatan : JumlahLPE $\times$ Jumlah Sampel LPD

Sehingga diperoleh jumlah sampel yang diambil setiap kecamatan di Kabupaten Gianyar yaitu:

Tabel 1.Alokasi Unit Sampel secara Proporsional

\begin{tabular}{cccc}
\hline No & Kecamatan & Jumlah LPD & $\begin{array}{c}\text { Jumlah LPD Terpilih Menjadi } \\
\text { Sampel }\end{array}$ \\
\hline 1 & Blahbatuh & 36 & 10 \\
2 & Gianyar & 40 & 11 \\
3 & Payangan & 48 & 13 \\
4 & Sukawati & 33 & 9 \\
5 & Tampaksiring & 36 & 10 \\
6 & Tegallalang & 45 & 12 \\
7 & Ubud & 32 & 8 \\
& Total & 270 & 73 \\
\hline
\end{tabular}

Sumber : LPLPD Kabupaten Gianyar, 2018

Pengumpulan data yang digunakan dalam penelitian ini adalah metode dokumentasi, yaitu teknik pengumpulan data dengan cara menggunakan jurnaljurnal, buku-buku, serta melihat dan mengambil data-data yang diperoleh dari laporan keuangan LPD yang terdaftar pada LPLPD Kabupaten Gianyar.

Analisis statistik yang digunakan adalah regresi linear berganda. Analisis regresi linear berganda dilakukan untuk mengetahui hubungan antara lebih dari dua variabel, yaitu satu variabel sebagai variabel dependen dan beberapa variabel lain sebagai variabel independen.

$$
Y=\alpha+\beta 1 X 1+\beta 2 X 2+\beta 3 X 3+\text { ei. }
$$

Keterangan:

$\mathrm{Y}=$ Profitabilitas

$\alpha=$ Bilangan konstan

$\beta 1, \beta 2, \beta 3=$ Koefisien regresi

$\mathrm{X} 1=$ Perputaran kas

X2 = Kecukupan modal

X3 = Risiko kredit

$\mathrm{ei}=$ Variabel pengganggu 


\section{HASIL DAN PEMBAHASAN}

Sampel yang digunakan dalam penelittian ini sebanyak 73 LPD dengan total observasian sebanyak 365 data observasian. Metode pengambilan sampel yang digunakan dalam penelitian ini yaitu metode probability sampling dengan teknik proportional stratified random sampling. Untuk menentukan proporsi sampelnya digunakan rumus Slovin, sehingga diperoleh 73 LPD sebagai sampel. Sebelum melakukan analisis regresi linear berganda, dilakukan uji asumsi klasik salah satunya uji normalitas. Berikut merupakan hasil uji normalitas pada penelitian ini.

Tabel 2. Hasil Uji Normalitas

\begin{tabular}{llr}
\hline & & $\begin{array}{c}\text { Unstandardized } \\
\text { Residual }\end{array}$ \\
\hline $\mathrm{N}$ & & 365 \\
Normal Parametersa,b & Mean & .0000000 \\
& Std. Deviation & .01546203 \\
Most Extreme Differences & Absolute & .082 \\
& Positive & .082 \\
Kolmogorov-Smirnov Z & Negative & -.072 \\
Asymp. Sig. (2-tailed) & & 1.558 \\
\hline
\end{tabular}

Sumber: Data Penelitian, 2018

Hasil uji normalitas pada tabel diatas menujukkan bahwa model uji dengan 365 pengamatan tidak memenuhi asumsi normalitas data. Berdasarkan tabel di atas terlihat nilai Asymp. Sig (2-tailed) sebesar 0,016 dan hasil tersebut lebih kecil dari 0,05. Hal ini berarti seluruh data pada model persamaan regresi dengan profitabilitas sebagai variabel dependen tidak berdistribusi secara normal. Solusi yang bisa digunakan agar data tersebut terdistribusi normal adalah dengan membuang data outlier yang ada sehingga jumlah pengamatan dalam penelitian ini sebanyak 295 pengamatan selama periode 2013-2017. Jadi sebanyak 14 LPD dianggap sebagai outliers. Menurut Ghozali (2011:41) outlier merupakan kasus atau data yang memiliki karakteristik unuk yang terlihat sangat berbeda jauh dari obeservasi-observasi lainnya dan muncul dalam bentuk nilai ekstrim baik untuk sebuah variabel tunggal atau variabel kombinasi. Ghozali (2011:41) menyebutkan terdapat 4 penyebab timbulnya data outlier yaitu (1) kesalahan dalam mengentri data, (2) gagal menspesifikasikan adanya missing value dalam program komputer, (3) outlier bukan merupakan anggota populasi yang kita ambil sebagai sampel, tetapi (4) outlier berasal dari populasi yang kita ambil sebagai sampal, tetapi distribusi dari variabel dalam populasi tersebut memiliki nilai ekstrim dan tidak berdistribusi secara normal. Pendeteksian terhadap data outlier dapat dilakukan dengan menentukan nilai batas yang akan dikategorikan sebagai data outlier yaitu dengan cara mengkonversi nilai data ke dalam skor standardized atau yang biasa disebut $z$-score. Setelah menghilangkan data outlier, dilakukan pengujian kembali pada penelitian ini. Hasil statistik deskriptif setelah outlier pada penelitian ini dapat dilihat pada Tabel 3.

Tabel 3.Hasil Uji Statistik Deskriptif 


\begin{tabular}{lrrrrr}
\hline & N & Minimum & Maximum & \multicolumn{1}{c}{ Mean } & Std. Deviation \\
\hline ROA & 295 & .01 & .09 & .0327 & .01820 \\
Perputaran Kas & 295 & .53 & 67.15 & 11.0019 & 10.97430 \\
CAR & 295 & .04 & .48 & .2155 & .10535 \\
NPL & 295 & .00 & .55 & .1273 & .11123 \\
Valid N (listwise) & 295 & & & & \\
\hline
\end{tabular}

Sumber: Data Penelitian, 2018

Berdasarkan Tabel 3. dapat dijelaskan statistik deskriptif dari variabel profitabilitas yang diukur dengan menggunakan ROA menunjukkan nilai minimum sebesar 0,01 dengan nilai maksimum sebesar 0,08. Sedangkan nilai rata-rata ROA sebesar 0,0327 dan nilai standar deviasi untuk ROA sebesar 0,01820. Ini menunjukkan bahwa profitabilitas LPD di Kabupaten Gianyar rata-rata bisa dikatakan baik, sebab nilai standar deviasi yang lebih kecil dari nilai rata-ratanya. Variabel perputaran kas menunjukkan nilai minimum sebesar 0,53 dengan nilai maksimum sebesar 67,15. Sedangkan, nilai rata-rata perputaran kas sebesar 11,0019 dan nilai standar deviasi perputaran kas sebesar 10,97430. Ini menunjukkan bahwa perputaran kas LPD di Kabupaten Gianyar rata-rata bisa dikatakan baik, dikarenakan nilai standar deviasi yang lebih kecil dari nilai rata-ratanya.

Variabel kecukupan modal yang diukur dengan menggunakan CAR menunjukkan nilai minimum sebesar 0,04 dengan nilai maksimum sebesar 0,48. Sedangkan rata-rata CAR sebesar 0,2155 dan nilai standar deviasi untuk CAR sebesar 0,10535. Secara statistik CAR berada dalam batas aman, yaitu dengan nilai rata-rata CAR lebih besar dari ketentuan pemerintah sebesar 12\%. Ini menunjukkan bahwa kecukupan modal LPD di Kabupaten Gianyar sudah bagus dan sebagian besar LPD sudah mampu menangani dan menanggung resiko-resiko yang mungkin akan dihadapi. Variabel risiko kredit yang diukur dengan menggunakan NPL menunjukkan nilai minimum sebesar 0,00 dengan nilai maksimum sebesar 0,55 . Sedangkan nilai ratarata NPL sebesar 0,1273 dan nilai standar deviasi untuk NPL sebesar 0,11123. Ini menunjukkan bahwa NPL LPD di Kabupaten Gianyar rata-rata dikatakan baik, karena nilai standar deviasi yang lebih kecil dari nilai rata-ratanya.

Pengujian normalitas data penelitian ini menggunakan metode KolmogorovSmirnov. Data penelitian dikatakan berdistribusi normal apabila nilai Asymp. Sig (2tailed) lebih besar daripada tingkat signifikansi sebesar 5\% atau 0,05. Berikut hasil uji normalitas penelitian dapat dilihat pada Tabel 4.

Tabel 4.Hasil Uji Normalitas

\begin{tabular}{lrr}
\hline & One-Sample Kolmogorov-Smirnov Test & Unstandardized Residual \\
\hline $\mathrm{N}$ & & 295 \\
Normal Parametersa, & Mean & .0000000 \\
& Std. Deviation & .01217398 \\
Most Extreme Differences & Absolute & .078 \\
& Positive & .078 \\
Kolmogorov-Smirnov Z & Negative & -.046 \\
Asymp. Sig. (2-tailed) & & 1.334 \\
\hline
\end{tabular}

Sumber: Data Penelitian, 2018

Berdasarkan tabel 4. nilai Asymp. Sig (2-tailed) adalah sebesar 0,057 yang lebih besar daripada 0,05 . Hal ini berarti bahwa seluruh data pada model persamaan regresi dengan variabel dependen profitabilitas sudah berdistribusi secara normal. 
Uji multikolinieritas adalah pengujian yang bertujuan untuk menguji apakah dalam model regresi ditemukan adanya kolerasi antarvariabel independen. Hasi uji multikolinieritas dapat dilihat pada Tabel 5.

Tabel 5. Hasil Uji Multikolinieritas

\begin{tabular}{lccc}
\hline & Variabel & Tolerance & VIF \\
\hline Perputaran kas & & 0,952 & 1,051 \\
Kecukupan modal & & 0,989 & 1,011 \\
Risiko kredit & 0,949 & 1,054 \\
\hline
\end{tabular}

Sumber: Data Penelitian, 2018

Berdasarkan Tabel 5. dapat dilihat bahwa nilai tolerance pada masing-masing variabel lebih besar dari 10\% $(0,1)$, demikian pula dengan nilai VIF masing-masing variabel yang lebih kecil dari 10. Hal ini menandakan bahwa pada persamaan regresi linier berganda dengan variabel dependen profitabilitas ini tidak terdapat korelasi antar variabel bebas sehingga persamaan ini bebas dari gejala multikolinearitas.

Uji heterokedastisitas digunakan untuk menguji apakah dalam sebuah model regresi berganda terjadi ketidaksamaan varians dari residual satu pengamatan ke pengamatan lainnya. Hasil uji heterokedastisitas dapat dilihat pada Tabel 6. berikut.

Tabel 6. Hasil Uji Heterokedastisitas

\begin{tabular}{lcl}
\hline \multicolumn{1}{c}{ Variabel } & Sig. & Keterangan \\
\hline Perputaran kas & 0,700 & Bebas heteroskedasitas \\
Kecukupan modal & 0,187 & Bebas heteroskedasitas \\
Risiko kredit & 0,451 & Bebas heteroskedasitas
\end{tabular}

Sumber: Data Penelitian, 2018

Berdasarkan Tabel 6. menunjukkan bahwa nilai signifikansi untuk variabel perputaran kas $\left(X_{1}\right)$ sebesar 0,700 , untuk variabel kecukupan modal $\left(X_{2}\right)$ sebesar 0,187 dan untuk variabel risiko kredit sebesar $\left(X_{3}\right)$ 0,451, masing-masing lebih besar dari 0,05. Hal ini menunjukkan bahwa model regresi bebas dari gejala heteroskedastisitas.

Setelah dipastikan bahwa model regresi memenuhi persyaratan uji asumsi klasik, maka model dapat dikatakan baik untuk menguji hipotesis penelitian. Hipotesis penelitian diuji dengan menggunakan analisis regresi linear berganda. Analisis ini digunakan untuk mengetahui besarnya pengaruh perputaran kas yang diukur dengan perbandingan antara penjualan bersih dengan jumlah rata-rata kas $\left(X_{1}\right)$, kecukupan modal yang diproksikan dengan $\mathrm{CAR}\left(\mathrm{X}_{2}\right)$, dan risiko kredit yang di proksikan dengan NPL $\left(X_{3}\right)$, pada Profitabilitas yang diproksikan dengan ROA $(Y)$ di LPD yang terdapat di Kabupaten Gianyar. Hasil olahan data dengan SPSS menggunakan model analisis regresi linear berganda dapat dilihat pada Tabel 7. sebagai berikut:

Tabel 7.Hasil Analisis Regresi Linear Berganda

\begin{tabular}{|c|c|c|c|c|c|c|}
\hline \multirow{2}{*}{\multicolumn{2}{|c|}{ Model }} & \multicolumn{2}{|c|}{$\begin{array}{l}\text { Unstandardized } \\
\text { Coefficients }\end{array}$} & \multirow{2}{*}{$\begin{array}{l}\text { Standardized } \\
\text { Coefficients } \\
\text { Beta }\end{array}$} & \multirow[b]{2}{*}{$\mathrm{t}$} & \multirow[b]{2}{*}{ Sig. } \\
\hline & & $\mathrm{B}$ & Std. Error & & & \\
\hline \multirow[t]{4}{*}{1} & (Constant) & .008 & .002 & & 3.631 & .000 \\
\hline & $\mathrm{X}_{1}$ & .001 & .000 & 106 & 2.645 & .009 \\
\hline & $X_{2}$ & .122 & .007 & .707 & 17.945 & .000 \\
\hline & $X_{3}$ & -.026 & .007 & -.159 & -3.938 & .000 \\
\hline
\end{tabular}

Sumber: Data Penelitian, 2018

Hasil analisis regresi linear berganda pada Tabel 7.dapat dibuat persamaan sebagai berikut:

$$
Y=0,008+0,106 X 1+0,707 X 2-0,159 X 3+\varepsilon
$$

Berdasarkan persamaan regresi nilai konstanta $(\alpha)$ sebesar 0,008 berarti apabila perputaran kas $\left(X_{1}\right)$, kecukupan modal $\left(X_{2}\right)$ dan risiko kredit $\left(X_{3}\right)$ bernilai 0 , maka 
profitabilitas adalah sebesar 0,008 satuan. Nilai koefisien regresi perputaran kas $\left(\beta_{1}\right)$ sebesar 0,001 berarti apabila perputaran kas meningkat sebesar 1 satuan dengan anggapan variabel lainnya konstan, maka profitabilitas akan meningkat sebesar 0,001 satuan. Nilai koefisien regresi kecukupan modal $\left(\beta_{2}\right)$ sebesar 0,122 berarti apabila CAR meningkat sebesar 1 satuan dengan anggapan variabel lainnya konstan, maka profitabilitas akan meningkat sebesar 0,122 satuan. Nilai koefisien regresi risiko kredit $\left(\beta_{3}\right)$ sebesar $-0,026$ berarti apabila NPL meningkat sebesar 1 satuan dengan anggapan variabel lainnya konstan, maka profitabilitas akan cenderung mengalami penurunan sebesar 0,026 satuan.

Uji kelayakan model regresi bertujuan untuk mengetahui apakah semua variabel bebas yang diidentifikasi (perputaran kas, kecukupan modal, dan risiko kredit) tepat digunakan memprediksi profitabilitas. Uji ini sering juga disebut dengan uji F. Hasil uji F dapat dilihat pada Tabel 8.

Tabel 8.Hasil Uji F

\begin{tabular}{ccccccc}
\hline & Model & Sum of Squares & Df & Mean Square & F & Sig. \\
\hline \multirow{2}{*}{1} & Regression & 0,054 & 3 & 0,018 & 119,897 & $0,000^{\mathrm{a}}$ \\
& Residual & 0,044 & 291 & 0,000 & & \\
& Total & 0,097 & 294 & & & \\
& & &
\end{tabular}

Sumber: Data Penelitian, 2018

Hasil uji $\mathrm{F}$ (F test) pada Tabel 8. menunjukkan bahwa nilai $\mathrm{F}$ hitung sebesar 119,897 dengan nilai signifikansi $\mathrm{P}$ value 0,000 yang lebih kecil dari $\alpha=0,05$, ini berarti model yang digunakan pada penelitian ini adalah layak. Hasil ini memberikan makna bahwa seluruh variabel independen, yaitu perputaran kas, kecukupan modal, dan risiko kredit tepat memprediksi atau menjelaskan fenomena profitabilitas di LPD yang terdapat di Kabupaten Gianyar. Dengan kata lain, perputaran kas, kecukupan modal, dan risiko kredit secara simultan berpengaruh signifikan pada profitabilitas.

Uji hipotesis (uji t) digunakan untuk mengetahui apakah variabel bebas berpegaruh secara parsial pada variabel terikat. Untuk menentukan apakah hipotesis diterima atau ditolak adalah dengan melihat nilai signifikansi dalam penelitian ini menggunakan tingkat signifikansi 0,050. Beradasarkan Tabel 7, maka hasil pengujian pengaruh masing-masing variabel independen. Hasil regresi pada Tabel 7. menunjukkan bahwa perputaran kas berpengaruh positif pada profitabilitas. Arah koefisien regresi yang positif menunjukkan bahwa semakin besar tingkat perputaran kasnya maka semakin tinggi pula tingkat profitabilitas suatu LPD. Hal ini dikarenakan kas yang terdapat di LPD digunakan secara efisien sehingga tidak ada kas yang menganggur, tentu saja hal ini berpengaruh pada profitabilitas LPD tersebut. Hasil ini sesuai dengan penelitian yang dilakukan oleh Prawira (2012), Friskayanti (2014), dan Dewi (2014) yang menyatakan terdapat pengaruh yang positif dan signifikan antara tingkat perputaran kas dan profitabilitas LPD.

Hasil regresi pada Tabel 7. menunjukkan bahwa kecukupan modal berpengaruh positif pada profitabilitas. Arah koefisien regresi yang positif menunjukkan bahwa semakin tinggi tingkat kecukupan modal maka profitabilitas LPD akan meningkat. Hal ini karena apabila CAR dalam suatu LPD semakin tinggi maka tingkat likuiditasnya semakin tinggi pula. Sama halnya dengan profitabilitas LPD tersebut, apabila kecukupan modal semakin tinggi maka tingkat profitabilitas suatu LPD akan semakin tinggi. Selain itu apabila kecukupan modal LPD yang diukur dengan menggunakan CAR tinggi, maka kemampuan LPD untuk menutupi kemungkinan kerugian dan segala risiko yang terjadi semakin tinggi pula. Hasil ini sesuai dengan penelitian yang dikalukan oleh Ani et al. (2012), Pudja. (2014), Paramithari. (2016) serta Akhtar \& Ali 
(2011)yang menyatakan bahwa CAR berpengaruh positif pada pertumbuhan profitabilitas LPD.

Berdasarkan hasil regresi pada Tabel 7 menunjukkan NPL yang digunakan untuk mengukur variabel risiko kredit memiliki nilai yang negatif terlihat dari nilai koefisien regresinya sebesar $-0,026$. Hal ini berarti NPL memiliki nilai yang rendah sehingga risiko kredit suatu LPD rendah pula. Hal ini karena LPD mampu mengatasi risiko kerdit yang dihadapnya, sehingga profitabilitas LPD dapat meningkat. Jika nilai NPL tinggi maka risiko kredit yang dihadapi LPD tinggi pula sehingga pendapatan yang diharapkan tidak terwujud dengan maksimal. Semakin tinggi persentase kredit bermasalah, maka jumlah modal suatu LPD akan berkurang karena pendapatan yang seharusnya diperoleh digunakan untuk menutupi tingginya rasio kredit bermasalah sehingga mengurangi kepercayaan masyarakat terhadap LPD tersebut. Hasil ini sejalan dengan penelitian yang dilakukan oleh Ariani \& Ardiana (2015), Yanti \& Suryantini (2015), serta Norman et al. (2015) yang menyatakan NLP berpengaruh negatif terhadap profitabilitas.

\section{SIMPULAN}

Penelitian ini memiliki tujuan untuk mengetahui pengaruh perputaran kas, kecukupan modal dan risiko kredit pada profitabilitas LPD di Kabupaten Gianyar. Perputaran kas memiliki pengaruh positif pada perofitabilitas LPD di Kabupaten Gianyar. Hal ini memunjukkan bahwa LPD di Kabupaten Gianyar sudah menggunakan kasnya secara efisien sehingga perputaran kas LPD tinggi. Variabel kecukupan modal juga memiliki pengaruh yang positif pada profitabilitas LPD di Kabupaten Gianyar. Hal ini menunjukkan bahwa LPD di Kabupaten Gianyar sudah mampu untuk mengatasi kemungkinan risiko yang bisa terjadi pada LPD. Kemudian yang terakhir variabel risiko kredit memiliki pengaruh yang negatif pada profitabilitas LPD di Kabupaten Gianyar. Hal ini berarti LPD di Kabupaten Gianyar memiliki risiko kredit yang rendah sehingga pengembalian kredit ke LPD semakin tinggi yang tentu saja berpengaruh pada profitabilitas LPD.

Berdasarkan hasil penelitian diatas, saran yang bisa disampaikan kepada pihak LPD yaitu diharapkan mampu menjaga tingkat perputaran kas, kecukupan modal, serta risiko kredit. Hal ini dikarenaka variabel tersebut akan berpengaruh pada profitabilitas LPD serta demi bertahannya nilai kesehatan LPD itu sendiri. Peneliti selanjutnya yaitu hendaknya menambahkan variabel-variabel lainnya yang dianggap berpengaruh pula pada profitabilitas LPD, seperti rasio BOPO dan rasio CAMEL.

\section{REFERENSI}

Akhtar, M. F., \& Ali, K. (2011). Factors Influencing the Profitability of Islamic Banks of Pakistan. International Research Journal of Finance and Economics, 66(66), 1-8.

Ani, W.U., Ugwunta, D.O., Ezeudu, I.J., Ugwuanyi, G. O. (2012). An empirical assessment of the determinants of bank profitability in Nigeria: Bank characteristics panel evidence. Journal of Accounting and Taxation, 4(3), 38-43. https://doi.org/10.5897/JAT11.034

Atmaja, I. G. N. Y. D. (2018). Pengaruh Profitabilitas, Leverage , dan Modal Kerja Pada Nilai Perusahaan dengan CSR Sebagai Variabel Intervening. E-Jurnal Akuntansi Universitas Udayana, 24(1), 1-29.

Ardiana, Putu Agus dan Eka Sari, Luh Kartika. (2012). "Pengaruh Variabel Aset Lancar, Debt to Total Assets, Umur dan Jumlah Anggota Terhadap Rentabilitas Ekonomi". Jurnal Akuntansi dan Bisnis, 5 (2):h:126-138. 
Ariani, M. W., \& Ardiana, P. A. (2015). Pengaruh Kecukupan Modal, Tingkat Efisiensi, Risiko Kredit, dan Likuiditas Pada Profitabilitas LPD Kabupaten Badung. E-Jurnal Akuntansi Universitas Udayana, 13(1), 259-275.

Bratland, J. (2010). Capital Concepts as Insights into the Maintenance and Neglect of Infrastructure. The Independent Review, 15(1), 35-51.

Chen, L., \& Chen, S. (2011). The influence of profitability on firm value with capital structure as the mediator and firm size and industry as moderators. Investment Management and Financial Innovation, 8(3), 121-129.

Dania, N. L. A. P., \& Sujana, I. K. (2015). Pengaruh Capital Adequacy Ratio, Non Performing Loan, dan Loan to Deposit Ratio pada Profitabilitas. E-Jurnal Akuntansi Universitas Udayana, 13(3), 1100-1119.

Dewi, N. M. J. L. (2017). Faktor-Faktor yang Mempengaruhi Pertumbuhan Laba dan Dampaknya Terhadap Pertumbuhan Aset LPD di Kabupaten Gianyar. E-Jurnal Akuntansi Universitas Udayana, 19(1), 565-592.

Dewi, P. A. R. K., \& Dana, I. M. (2014). Pengaruh Perputaran Kas, LDR, dan CAR Terhadap Profitabilitas pada LPD Desa Bondalem. E-Journal Akuntansi Universitas Udayana, 169-182.

Friskayanti, M. E., Atmadja, A. W. T., \& Musmini, L. S. (2014). Pengaruh Tingkat Perputaran Kas, Peputaran Kredit, Biaya Operasional Pendapatan Operasional (BOPO), Kecukupan Modal dan Jumlah Nasabah Terhadap Profitabilitas ( Studi Pada LPD Kabupaten Buleleng Yang Terdaftar Pada LPLPD Periode 2009-2013 ). E-Journal S1 Ak Universitas Pendidikan Ganesha Jurusan Akuntansi S1, 2(1).

Gizaw, M., Kebede, M., \& Sujata. (2015). The impact of credit risk on profitability performance of commercial banks in Ethiopia. African Journal of Business Management, 9(2), 59-66. https://doi.org/10.5897/AJBM2013.7171

Haneef, S., Rana, M. A., \& Karim, Y. (2012). Impact of Risk Management on NonPerforming Loans and Profitability of Banking Sector of Pakistan Hailey College of Commerce University of the Punjab Hafiz Muhammad Ishaq Federal Urdu University of Arts, Science and Technology. International Journal of Business and Social Science, 3(7), 307-315.

Indah Lestari, I. G. A. O. S., \& Suartana, I. W. ayan. (2017). Pengaruh Tingkat Efisiensi, Risiko Kredit, dan Tingkat Penyaluran Kredit pada Profitabilitas Lembaga Perkreditan Desa (LPD). E-Jurnal Akuntansi Universitas Udayana, 19(2), 1661-1690.

Jiang, P., \& Rosenbloom, B. (2005). Customer intention to return online: price perception, attribute-level performance, and. European Journal of Marketing, 39(1), 150-174. https://doi.org/10.1108/03090560510572061

Kosmidou, K., \& Zopounidis, C. (2008). Measurement of Bank Performance in Greece. South-Eastern Europe Journal of Economics, 1, 79-95.

Krisna Ekayana Suputra, I. P., \& Ratnadi, N. M. D. (2017). Pengaruh Rasio Beban dan Pendapatan Operasional, Nonperforming Loan, Loan To Deposit Pada Pertumbuhan Profitabilitas. E-Journal Akuntansi Universitas Udayana, 21(3), 20812107.

Lee, S. J., \& Rose, J. D. (2010). Profits and Balance Sheet Developments at U . S . Commercial Banks in 2009. Profits and Balance Sheet Developments at U.S. Commercial Banks in 2009, 1985(May), 1-37.

Lely Aryani Merkusiwati, Ni Ketut .(2007). Evaluasi pengaruh CAMEL terhadap Kinerja Perusahaan. Buletin Studi Ekonomi, Vol 12(1).

Manik, A. A. N. Y., Pramartha, \& Wirasedana, I. W. P. (2018). Pengaruh Pertumbuhan $\mathrm{K}$ redit pada Profitabilitas dengan Tingkat Perputaran Kredit Sebagai Variabel 
Pemoderasi pada LPD Kediri. E-Jurnal Akuntansi Universitas Udayana, 22(3), 17711799.

Mirah Siswandari, A.A. (2016). Pengaruh Ukuran Perusahaan, Umur Operasional, dan Capital Adequacy Ratio (CAR) Terhadap Kemampulabaan Lembaga Perkreditan Desa (LPD) di Kabupaten Gianyar. Skripsi. Fakultas Ekonomi dan Bisnis Universitas Udayana.

Noman, A. H., Pervin, S., \& Chowdhury, M. M. (2015). The Effect of Credit Risk on the Banking Profitability: A Case on Bangladesh. Global Journal of Management and Business Research: C Finance, 15(3).

Obicks,Wintara. (2010). Pengaruh Tingkat PerputaranKas, Loan To Deposit Ratiodan Tingkat Kecukupan Modal pada Rentabilitas Ekonomis Lembaga Perkreditan Desa (LPD) Kota Denpasar. Skripsi Sarjana Akuntansi Fakultas Ekonomi Universitas Udayana, Bali.

Olalekan, A., \& Adeyinka, S. (2013). Capital Adequacy and Banks â€TM Profitability: An Empirical Evidence From Nigeria. American International Journal of Contemporary Research, 3(10), 87-93.

Paramithari, N. M. P., \& Sujana, I. K. (2016). Kemampuan Capital, Asset, Earnings, dan Liquidity Memengaruhi Pertumbuhan Laba pada LPD Kabupaten Badung. EJournal Akuntansi Universitas Udayana, 17(8), 141-173.

Peraturan Gubernur Bali Nomor 44 Tahun 2017 tentang Lembaga Perkreditan Desa.

Prawira, I. W. A. B., \& Wisadha, I. G. S. (2012). Pengaruh Tingkat Perputaran Kas, Pertumbuhan Kredit, dan Rasio BOPO pada Profitabilitas LPD di Kota Denpasar Periode 2006-2010. E-Journal Akuntansi Universitas Udayana.

Pudja, N. M. A. D. (2014). Pengaruh Perputaran Kredit, Kecukupan Modal, dan Jumlah Nasabah pada Profitabilitas. E-Journal Akuntansi Universitas Udayana, 8(3), 584597.

Rahma, A. (2011). Analisis Pengaruh Manajemen Modal Kerja Terhadap Profitabilitas Perusahaan (Studi pada Perusahaan Manufaktur PMA dan PMDN yang Terdaftar di BEI periode 2004-2008). Universitas Diponegoro, Semarang, 1-25.

Ramantha, I Wayan. (2006). Menuju LPD Bali yang Sehat. Buletin Studi Ekonomi. 11(1). Denpasar.

Riyadi, Selamet. (2006). Banking Assets and Liability Management: Edisi Ketiga. Jakarta: Lembaga Penerbitan Fakultas Ekonomi Universitas Indonesia.

Riyanto, Bambang. (2011). Dasar-Dasar Pembelanjaan Perusahaan Edisi Keempat. BPFE: Yogyakarta.

Rustiarini, N. I. W. (2010). Pengaruh Corporate Governance pada Hubungan Corporate Social Responsibility dan Nilai Perusahaan. Simposium Nasional Akuntansi XIII Purwokerto, (11), 1-24.

Sari, R. C., \& Zuhrohtun. (2008). Keinformatifan laba di pasar obligasi dan saham: uji. Jurnal Ilmiah Akuntansi Universitas Udayana, 3, No. 1.

Sukarno, K. W., \& Syaichu, M. (2006). Analisis Faktor-Faktor yang Mempengaruhi Kinerja Bank Umum di Indonesia. Jurnal Studi Manajemen \& Organisasi, 3, 46-58.

Suteja Putra, I. W., \& Wirajaya, I. G. A. (2013). Pengaruh Tingkat Perputaran Kas, Piutang dan Jumlah Nasabah Kredit pada Profitabilitas LPD di Kecamatan Ubud. E-Jurnal Akuntansi Universitas Udayana, 3(1), 119-135.

Sutika, I. K., \& Sujana, I. K. (2013). Analisis Faktor Kinerja yang Mempengaruhi Profitabilitas pada Lembaga Perkreditan Desa. E-Journal Akuntansi Universitas Udayana, 5(1), 68-84.

Slamat, Dahlan. (2001). Manajemen Lembaga Keuangan. Edisi Ketiga. Jakarta: 
Universitas Indonesia

Sugiyono. (2017.) Metode Penelitian Kualitatif dan Kuantitatif dan RED. Jakarta: Alfabeta

Vong, Anna P. I. \& Chan, H. S. (2009). Determinants of Bank Profitability in Macao. Journal Faculty of Business Administratiom, University of Macau, (January 2006), 93 113.

Williams, H. T. (2011). Determinants of capital adequacy in the Banking Sub-Sector of the Nigeria Economy: Efficacy of Camels . ( A Model Specification with CoIntegration Analysis ). International Journal of Academic Research in Business and Social Sciences, 1(3).

Wirawan, Nata. (2002). Cara Mudah Memahami Statistic 2 (statistik inferensia). Denpasar: Keraras Emas.

Wiwoho, J. (2014). Peran Lembaga Keuangan Bank dan Lembaga Keuangan Bukan Bank dalam Memberikan Distribusi Keadilan bagi Masyarakat. $M M H, 43(1), 87-$ 97.

Yanti, F. A. K., \& Suryantini, N. P. S. (2015). Pengaruh Dana Pihak Ketiga, Kecukupan Modal, Risiko Kredit dan Likuiditas Terhadap Profitabilitas LPD Kabupaten Badung. E-Jurnal Manajemen Unud, 4(12), 4362-4391.

Yuanjuan, L., \& Shishun, X. (2012). Effectiveness of China â€TM s Commercial Banks $\hat{\mathrm{a}} €^{\mathrm{TM}}$ Capital Adequacy Ratio Regulation. Interdisciplinary Journal of Contemporary Research in Business, 4(1), 58-68.

Zimmerman, G. C., \& Levonian, M. (1996). Factors Influencing Community Bank Performance in California. FRBSF Economic Review, 1, 26-42. 